\title{
Human Factors: Spanning the Gap between OM \& HRM
}

\author{
W. Patrick Neumann
}

Ryerson University

\section{Jan Dul}

Erasmus University

\section{digital.library.ryerson.ca/object/167}

\section{Please Cite:}

Neumann, W. P., \& Dul, J. (2010). Human factors: Spanning the gap between $\mathrm{OM}$ and HRM. International Journal of Operations \& Production Management, 30(9), 923-950.

doi:10.1108/01443571011075056

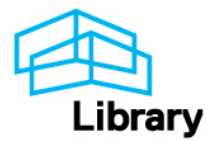




\title{
Human Factors: Spanning the Gap between OM \& HRM
}

\author{
W. Patrick Neumann ${ }^{1^{*}}$ and Jan Dul $^{2}$
}

* Corresponding Author

${ }^{1}$ W. Patrick NEUMANN

Assistant professor of Human Factors Engineering

Ryerson University

Department of Mechanical and Industrial Engineering

350 Victoria St.

Toronto, ON

Canada, M5B2K3

Phone : +1 4169795000 x7738

Fax: +1 4169795265

Email: pneumann@ryerson.ca

Web: http://www.ryerson.ca/pneumann

\section{${ }^{2}$ Jan DUL}

Professor of Technology and Human Factors

Department of Management of Technology and Innovation

Rotterdam School of Management,

Erasmus University,

P.O. Box 1738

3000 DR Rotterdam

The Netherlands

Phone: +31 104081719

Fax: +31 104089014

Email: jdul@rsm.nl

Web: http://www.rsm.nl/jdul 


\section{Acknowledgements}

This work has been supported by the Erasmus Research Institute of Management of the Erasmus University Rotterdam, the SMARTA theme of the former Swedish National Institute for Working Life, and by the Canadian National Science and Engineering Research Council (NSERC \#341664-07). The authors are grateful for the assistance of librarian Maria Nylander and assistants Avninder Buttar and Anna Shaliganova in collecting data for this review and Dr. René de Koster for suggestions on drafts of this paper. The authors contributed equally to this article. 


\title{
Literature Review
}

\section{Human Factors: Spanning the Gap between OM \& HRM}

\begin{abstract}
Purpose: This paper examines the claim that the application of human factors (HF) knowledge can improve both human well-being and operations system performance.

Methodology: A systematic review was conducted using a general and two specialist databases to identify empirical studies addressing both human effects and operations system effects in examining manufacturing operations system design aspects.
\end{abstract}

Findings: We found 45 empirical studies addressing both the human effects and system effects of operations system (re)design. Of those studies providing clear directional effects, 95\% showed a convergence between human effects and system effects (+,+ or -,-), 5\% showed a divergence of human and system effects (+,- or -,+). System effects included quality, productivity, implementation performance of new technologies, and also more 'intangible' effects in terms of improved communication and co-operation. Human effects included employee health, attitudes, physical workload, and 'quality of working life'.

Research limitations/implications: Future research should attend to both human and system outcomes in trying to determine optimal configurations for operations systems as this appears to be a complex relationship with potential long-term impact on operational performance.

Practical implications: The application of HF in operations system design can support improvement in both employee well-being and system performance in a number of manufacturing domains.

Originality/value: This paper outlines and documents a research and practice gap between the fields of HF and OM research that has not been previously discussed in the management literature. This gap may be inhibiting the design of operations systems with superior long term performance. 


\section{Keywords}

human factors, sustainable competitiveness, productivity, health, operations design, production planning 


\section{Introduction}

Many companies rely on humans. In recent years there has been an increasing interest in human issues in operations management (Boudreau et al., 2003; Cook et al., 2002; Juran and Schruben, 2004; Wirojanagud et al., 2007; Yee et al., 2008). Humans are part of operations systems, both as decision-making managers and system operators. Operations Management (OM) practitioners recognise the importance of humans implicitly and OM textbooks contain sections on human factors (e.g. Heizer and Render, 2007; Wild, 1995), but the topic is infrequently covered in OM research journals. Where humans are included, severe simplifications of human characteristics and behaviour are made such as “people have predictable behaviour” or "people are constant without tiredness” (Boudreau et al., 2003). One discipline that could give realistic human input to operations management is the discipline of Human Factors (HF). We accept the definition of Human Factors as : "the scientific discipline concerned with the understanding of interactions among humans and other elements of a system ... in order to optimize human wellbeing and overall system performance.” (IEA Council, 2000). This definition of human factors spans both the physical, cognitive, and psychosocial interface between the operator and the operations system and is operationally defined as synonymous with the term 'ergonomics' (c.f. IEA Council, 2000) which is sometimes seen as a narrower issue by those outside the discipline. HF differs from Human Resource Management (HRM) in that HRM focuses more on selecting and developing people in order to fit them to the system, whereas HF focuses on adapting the system design in order to fit it to the people ("human factors engineering"). In the next section we will examine the separation of HF from OM in science and society that underlies the need for this study.

\subsection{The Separation of $\mathrm{HF}$ and $\mathrm{OM}$}

The possible contribution of HF to OM may be hampered by the fact that the HF literature is separated from the OM literature. HF publications mainly appear in journals focusing on human 
well-being (e.g. psychological, medical and ergonomics journals) and rarely in business and management journals. A review of articles in 97 business and management journals, including popular journals like Harvard Business Review and Fortune, during a 10-year period, revealed that in 90 journals (93\%) no HF paper at all was published, with a total of 10 articles in 10 years appearing in 7 (7\%) different journals (Dul, 2003). A survey in Ireland found that over $36 \%$ of companies claim no knowledge of human factors whatsoever (James et al., 1994) and amongst managers in developing nations this figure rises to $88 \%$. This knowledge gap may be limiting firms’ ability to profit from application of HF principles in their operations system (OS) designs.

A second reason for the gap between HF and OM may be the misperception of HF as strictly a Health and Safety (H\&S) tool to be positioned as part of HRM (Hägg, 2003). Jenkins and Rickards (2001) describe the problem thus: “[HF]... is still often viewed by management as a means to prevent injuries, while providing no return on investment. This mentality serves to hide the potential... to improve labour efficiency and reduce the cost of production” (Jenkins and Rickards, 2001, p 234). As a result, few companies have integrated HF thinking with the firm’s strategy or operations improvement processes (Dul and Neumann 2009). By isolating HF as an H\&S issue, separate from core OM decisions, it is in an organisational 'side-car' with limited influence and reduced ability to contribute to core system goals and performance (Frick, 1994; Jensen, 2001). The total (direct and indirect) costs of work-related ill health (WIH), however, are immense and have been calculated to exceed costs for coronary heart disease, and are roughly on par with the total costs of all cancers combined (Leigh et al., 1997). The World Health Organisation reports the costs of work-related ill health at 4-5\% of the total global domestic product (WHO, 1999). The extent to which firms must carry the direct and indirect costs of WIH will vary with legislative context. The total costs of poor HF in OS design, of 
which injury costs are only a small sub-set, are rarely calculated by companies and are rarely studied from an OM perspective. HF science may be able to contribute here.

A third possible contributor to the HF-OM gap is the gradual shift of management research away from its original ideas of serving firms and society (including human well-being) to a more exclusive focus on firm profitability and a growing disinterest in issues with any ethical implications (Walsh et al., 2003). While this might be counter-indicated by the current interest in corporate social responsibility (CSR), CSR is frequently discussed in terms of profit in the OM literature (e.g.Salzmann et al., 2005; Weber, 2008). Interest in CSR notwithstanding, Walsh et al. (2003) have suggested that ethics and social agenda issues have lost credibility within the management and research community. We argue that, if $\mathrm{H} \& S$, and again by association HF, is seen as only an ethical issue and not a issue for firm profitability then it will again be isolated in the minds of management researchers and this could limit HF's ability to contribute to firm performance.

These three elements; the separation of HF from business and management literatures, the misperception of HF as strictly a H\&S tool to be positioned in HRM, and the loss of credibility of social objectives in management research, may have contributed to a 'dominant logic' in which HF has little to offer in helping organisations reach their strategic goals. Prahalad (2004) has described how 'dominant logic' creates barriers, or 'blinders', that can prevent managers from recognising innovative potential and results in missed opportunities for the firm. This, we argue, is what has happened to HF. There remains, therefore, a need to examine scientific research in this area if the full potential of the operations system is to be realised. This paper presents a framework and a systematic literature review examining the claim that application of HF knowledge in OS design can improve results in terms of both operator well-being and overall system performance. 


\subsection{A framework for studying effects of operations system design}

Our framework is presented in Figure 1. The focal unit is any operations system (OS). The OS is operationally defined as the 'bundle of measures' that have been implemented in the realisation of the operations system including both technological and organisational characteristics (Brassler and Schneider, 2001). This includes the operators and the technical equipment, its configuration, and the approach by which work is organised into jobs and tasks for operators to perform - a view generally consistent with sociotechnical view of work systems (Eijnatten et al., 1993). The technical and organisational design features of the OS are the independent concepts; and the human effects and system effects the dependent concepts. System effects include the traditional production indicators quality and productivity, as well as new technology implementation performance (process innovation) and ‘intangible’ effects like communication culture or industrial relations. Human effects are defined as the physical and psychological consequences that the operations system has for system operators. This includes effects on health (e.g. pain or injury), worker attitudes (e.g. boredom or satisfaction), physical work load, and general effects on safety (e.g. from accident risk) or the quality of working life (e.g. improved communications and cooperation). To illustrate: the height of a box on a shelf and the process by which an operator is assigned to that station are characteristics of the operations system, the physical workload for the operator to reach the box and any related discomfort are human effects (Figure 1, link A), and the act of manipulating the box contributes to the system effect of productivity (Link B). Since humans are part of the OS, any effects on humans will immediately influence their work performance, for better or worse.

Firm profitability is seen as distal to the more proximal effects discussed here.

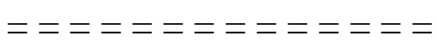

Insert Figure 1 about here

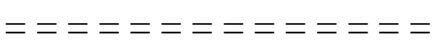


The implications of this framework are that any change in the technical or organizational characteristics of the operations system has both human effects (link A) and system effects (link B) with four possible outcomes (Table 1).

$$
==x===+==+
$$

Insert Table 1 about here $==\underline{=}=\underline{=}=\mathbf{=}==$

Hence, central to our model is that the set of design choices made during system (re)design lead simultaneously to both human and system effects. Design options should not, therefore, be considered for these two kinds of effects separately. From this we develop the claim that application of HF can secure improved outcomes in terms of both system effects and human effects. Typically, these two types of effects are studied separately by researchers in separate fields. For example, workplace health researchers have studied link A (Figure 1; human effects). OM researchers have traditionally studied link B (Figure 1; system effects). In this paper we conduct a systematic literature review to examine the available empirical evidence for the claimed dual effects: 'human' and 'system', of OS designs - the 'A and B' linkage in Figure 1. Such evidence would provide the rationale for the application of HF science in OS design. In this review we focus on operations systems with manual work (excluding white collar work) in manufacturing. We propose that according to HF claims, changes in the operations system will result in joint human effects and system effects - either both improving or both worsening together. This can be contrasted against the view that human and system effects are oppositional - gains in one aspect must come at the expense of the other. Empirical evidence supporting this proposition will be indicated by studies which explore the human and system effects of OS design changes, and show joint win-win or joint lose-lose effects (per Table 1). Studies showing lose-win or win-lose effects would counter the proposition. 


\section{Methods}

A systematic literature search was conducted with the assistance of research assistants and a professional librarian. The aim of this search was to identify peer-reviewed papers that presented empirical evidence on both the human and the system effects of operations system design changes in manufacturing - both ' $\mathrm{A}$ ' and ' $\mathrm{B}$ ' linkages in Figure 1. We excluded studies that focus on the relationship between human effects and system effects without linking these to operations system design characteristics (e.g. studies on the effects of physical workload on productivity, or studies relating motivation to performance), as we were interested in the dual effects of operations system design. Since the concepts 'human effects' and 'system effects' could not be defined with a few simple terms, a librarian chose an iterative approach in which a number of search terms relating to human effects were crossed (AND searched) with a number of different terms implying system effects. Initially chosen terms were supplemented with alternatives obtained from database thesaurus and index terms, as well as terms found in titles and abstracts from relevant references (See Table 2 for a summary of final terms used).

$==+==+==+=$

Insert Table 2 about here $=\mathrm{x}=\mathrm{=}=\mathrm{=}=\mathrm{=}=\mathrm{=}$

These terms were applied in varying combinations to provide an overlapping web of search criteria using Boolean operators, wild-cards, truncation, phrase searching and 'find similar' functions whenever relevant (c.f. Harter, 1986). This search approach was applied to three databases: Web of Science, an all purpose scientific database, and a specialty databases for each core topic area - Ergonomics Abstracts, and Business Source Elite. Articles included were limited to English language and published in ISI journals (journals indexed by Thomson Scientific's Institute of Scientific Information). Year of publication was not limited; searching was conducted in 2005. Further searching was performed in 2009. Results from this process 
were then examined to eliminate papers not actually providing empirical evidence addressing both human and system effects in the manufacturing sector (service sector was excluded in this search). Papers dealing with the financial benefits of health interventions were excluded as being 'only' health-focussed despite the reckoning of those benefits in financial terms - a distal outcome from the focus of the framework of Figure 1 (e.g. Halpern and Dawson, 1997; Hantula et al., 2001; Seeley and Marklin, 2003). Similarly papers correlating human and system effects without attention to the design of the operations system were excluded, although key papers of this type, along with relevant conceptual papers, were included in the discussion of the results presented.

Core results of each selected article were summarized in a table, and the articles were further analysed by sorting them into a 2x2 matrix in order to classify the selected papers into groups based on explicit statements confirming (win-win or lose-lose) and disconfirming (win-lose or lose-win) the HF proposition per Table 1 (above). A summary was also made of the types of journals, based on journal title in the categories of: 'Human Factors', 'Safety', 'Management' (including HR and Industrial relations), or 'Engineering'.

\section{RESULTS}

The original searching process yielded 603 non-duplicate articles of which 36 were eventually deemed relevant based on having both outcomes resulting from a given OS design. The secondary round of searching, conducted in 2009, yielded 9 additional studies for a total of 45 relevant non-duplicate studies. These papers and their key findings are summarised in alphabetical order in Table 5. The papers identified in this search covered a wide range of study designs including case studies of 'participatory' interventions, cases of system re-design, surveys in industrial sectors, longitudinal studies of industrial development, and tests of 
particular technical (e.g. equipment) solutions. The human effects considered varied widely in both construct and evaluation approach and are summarised in Table 3, showing an emphasis on physical workload (62\% of studies) and health (40\% of studies).

$==+==+==+=$

Insert Table 3 about here

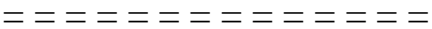

The observed system effects were mainly productivity (89\% of studies) and quality (31\% of studies). The distribution of articles by discipline is illustrated in Figure 2. HF Journals made up over half the study sample, while OM journals carried less than $10 \%$ of the identified studies with joint effects.

$===+==+==+$

Insert Figure 2 about here

$==+===+==+$

$==+==+==+=$

Insert Table 4 about here

$==+==+==+=$

In the 2x2 classification analysis, presented in Table 4, 4 papers were eliminated as inappropriate for inclusion as their results could not be reduced to simple win-lose terms. The study of Adler and colleagues' (Adler et al., 1997) that describe the trials and tribulations of a new model launch at an auto company manufacturer could not be so simply categorised. Similarly, three studies from a case-series (Neumann et al., 2002, Neumann et al. 2006, Kazmierzcak et al. 2007), applied a holistic approach to understand the human and system effects of a series of production system design choices, while the authors claim the need for such nuanced analysis it makes such studies inappropriate for the meta analysis conducted here. A further three papers, with observed null-effect in one dimension, were also excluded from 
this analysis because these cannot be classified in a win-lose table: Bao et al., 1996, Rhijn et al. 2005, and Dababneh et al. 2001. The remaining 38 papers were classified according to the 2x2 classification matrix in Table 4 which shows that $95 \%$ of the sample is consistent with a joint win-win or lose-lose relationships between human and system effects. Hence, there is empirical evidence for the hypothesis that changes in the operations system will result in joint human effects and system effects, with most papers showing win-win outcomes. Two of the 'lose-lose’ papers demonstrated linkages between postural and workload deficits for operators and quality deficits (Eklund, 1995; Lin et al., 2001) and the third showed that companies with more health problems have more productivity problems (Shikdar and Sawaqed, 2003). The papers with a 'null effect', that were excluded here, could be considered as counter to the 'oppositional' hypothesis - that human and system effects conflict. Finally, two papers (about 5\%) had win-lose type findings countering the HF claim; these will be discussed in more detail.

$===+==+==+$

Insert Table 5 about here $==+==+==+=$

\section{DISCUSSION}

From a pool of hundreds of thousands of scientific articles in both business and human factors databases, only 45 empirical studies were identified, using the current search approach, that studied both the human and system effects of the design of operations systems in manufacturing. Over two thirds of these studies are published in HF or Safety journals while fewer than 10\% are from OM or Management Science Journals and 15\% are from Engineering journals. Given the thousands of articles published annually in each domain, we see this as an indication of lack of either researcher interest in, or capability to explore OS design choices’ effects in both human and system dimensions. This can be seen as a confirmation of the research gap between these disciplines which may contribute to the underperformance of OS 
design efforts in manufacturing. This lack of studies of joint effects is also consistent with a dominant logic perceiving HF as a health matter with limited potential to contribute to OS performance. In contrast to our 45 papers, a review of system effects of manufacturing strategy found 260 relevant articles (Dangayach and Deshmukh, 2001) - without a single study that included human factors. Furthermore, many studies (e.g. laboratory studies) exist on the relationship between 'human effects' (such as posture) and 'system effects' (such as productivity), however without incorporating the operations system that could cause these effects (e.g., cellular production). While a few of the selected studies reported perverse relationships between human and system effects, the vast majority (95\%) of the studies identified in our review report joint human and system effects resulting from the design of the operations system. These studies covered a broad range of both technical and organisational aspects of OS design that would be considered in both 'managerial' and 'engineering' domains. Most studies analysed the OS at company level, whereas few studies dealt with a broader level (sector) or a narrower level (workstation, equipment) with consistent results.

The two counterexamples warrant closer examination: Lutz et al. (2000) in developing mirror devices to improve vision and reduce awkward postures during assembly tasks (screw running) found improved postures, but degraded performance for workers who were inexperienced in using the mirror device - while the authors note performance-learning effects they did not extend testing to see if screw running performance with the mirrored-screw driving devices eventually reached that of a normal screwdriver or beyond. Moreau (2003) summarising Peugeot's approach to ergonomics noted that “denser” task cycles (presumed to provide a productivity benefit) lead to increased musculoskeletal disorders in operators - a result consistent with physiological pathomechanisms for myalgia (Hagberg et al., 1995; National Research Council, 2001). A number of studies included more complex analysis, either of industrial development over time (Adler et al., 1997), or of the interactions of a bundle of 
implemented OS design measures (Neumann et al., 2006). While these studies illuminate important issues for OS design, they are not amenable to the simple win-win type analysis conducted here. These studies help confirm the relation between OS design and joint human and system outcomes without contradicting the general findings of this meta-analysis. Overall, we interpret the studies identified in this review as suggesting that there is a good potential to have both joint positive human and positive system effects by attending to HF in the design of the operations system - but counter-examples suggest that this performance gain is not guaranteed.

The system benefits observed in the reviewed literature are generally consistent with the 'Resource-Based View' (RBV) of the firm which suggests that firm competitiveness is a product of exploiting resources that are valuable and difficult to replicate (Barney, 1991; Barney and Wright, 1998). The social (human) sub-system in an OS poses a 'resource' that is much more difficult to replicate than the technological subsystems of the OS (Pfeffer, 1994). HF science may be able to help managers realise the competitive advantage of the resources their employees represent. We suggest that HF is not an objective like health and safety and is instead a means which can support many company objectives (Dul and Neumann, 2009). Capitalising on this means, however will require managers to have a better understanding of how HF can help in the creation of OS's that are sustainably competitive.

Our study has a number of limitations. Methodologically, every 'systematic' review will have weaknesses and blind spots - there may be relevant literature that is missed, despite extensive efforts by the authors, research assistants and a librarian to identify relevant articles. This was aggravated by the breadth of the concepts under study and related research fields which needed to be considered. We have limited our search to publications in ISI journals, whereas relevant articles may have been published elsewhere as well. However it is unlikely that this has biased 
our results substantially given the weight of the trend that we found. Publication bias, caused by the difficulty in publishing studies with negative results, may also skew the results of a literature review (Dickersin and Min, 1993; Torgerson, 2006). In this case we suggest that publication bias may hide difficulties in applying HF but does not negate the apparent success some firms have had in improving performance by using HF. The classification of the publications was not always easy. Both 'human effects' and 'system effects' can be (and were) operationalized in many different ways, and some studies (e.g. Kazmierczak et al., 2007; Neumann et al., 2006) examined multiple design elements and their impact on different human effects (psychosocial and physical) and system effects (productivity, quality). The distinction between human and system effects can also become confused: Employee turnover, for example, noted to be reduced by HF applications (Abrahamsson, 2000; Oxenburgh and Marlow, 2005; Parenmark et al., 1993), could be interpreted as a positive effect in either the human or system domain. These problems notwithstanding we were able to identify general trends, and below we discuss the possible system effects of using HF principles in the design of operations systems: quality, productivity, new technology implementation performance, and intangible effects. Given the range of systems and the paucity of studies, it is not possible at this point to comment on the specific HF design features that should be applied to be useful to practitioners - more research is still needed.

\subsection{Human Factors and quality}

In our analysis, 14 studies reported a connection between HF design of the OS and quality performance. It is studies in this domain that report a 'double lose' relation in which poor postures and poor quality are joint outcomes of OS design. For example, Lin et al. (2001) found that $50 \%$ of the quality variance in the production lines was accounted for by a combination of the lack of time required for the task and postural deficiencies. Researchers Yeow and Sen (Sen and Yeow, 2003; Yeow and Sen, 2003; Yeow and Sen, 2004; Yeow and Sen, 2006) have 
conducted a series of cases in the electronics sector, each demonstrating how even retrofitting HF engineering design changes such as improved lighting and product redesign, can yield quantifiable profits from improved productivity and quality.

Quality has become an important competitive domain (Ghobadian and Gallear, 2001) that has been seen to have important links to human factors (Carayon et al., 1999; Drury, 2000; Eklund, 1995). According to Drury, "Quality is a function of technological and human factors, and is greatly influenced by ergonomics in its broadest sense. Errors in the process can... result in product unreliability, poor productivity or even injury to the workforce or product user" (Drury, 2000; abstract). Axelsson (Axelsson, 2000) found that jobs with poor postural ergonomics were 10 times more likely to have quality deficits than jobs with good ergonomics. Other studies have also shown a co-variation of human and quality effects, without considering the operations system (Dillard and Schwager, 1997; GAO, 1997; González et al., 2003; Govindaraju et al., 2001; Hendrick, 2003; Klatte et al., 1997; Kleiner, 1999; Tari and Sabater, 2006). Part of the effects observed here may be interpreted in terms of human error making which can be interpreted as a phenomena arising from the design of the system which fosters errors, as well as from the human operator's knowledge and ability to avoid or recover from errors (Reason, 1990).

The evidence and supporting theory both suggest that, when designing the operations system according to HF principles, it is possible to have joint positive human and positive quality effects. Research priorities in this domain include better operationalisation and quantification of the relationship between both product and workstations parameters that contribute to quality deficits. More intervention case studies in this domain would allow more nuanced metaanalyses which could help managers make wise choices early in OS design. 


\subsection{Human Factors and productivity}

Of the 40 studies (almost 90\% of our sample) reporting on joint outcomes, all but 2 reported joint positive human and positive productivity effects. In our dataset, Helander and Burri (1995) claim over \$130 million in savings due to HF-related changes at IBM. Lee (2005) found that the productivity gains of integrating HF into a TQM process outweighed the health related gains by 24 to 1 (direct versus indirect costs). De Looze et al. (2003) report productivity increases of $15-20 \%$ realised through a process of design that deliberately combined human factors and traditional assembly engineering (De Looze et al., 2003). These studies, amongst many similar studies (Abrahamsson, 2000; Lee, 2005) and the case series by Yeow and Sen, demonstrate how attention to HF at both systemic and work-station levels can yield improved system productivity, not only improved human effects.

This finding is echoed by reports not included in our analysis - studies that have adopted a broad (not just health-based) approach to human factors application there seems to be greater financial benefits from the productivity and quality gains than from the savings due to reduced ill-health (Koningsveld, 2003; Loeppke et al., 2007). Oxenburgh et al., in presenting an economic model for evaluating simple workplace changes, demonstrated return on investments (ROI) of 1-2 months (Oxenburgh et al., 2004). Hendrick (2003), describes large scale design projects with ROIs of 18 months and returns in the $10: 1$ range. ROIs as high as $800 \%$ to $6000 \%$ have been reported from the application of HF principles in redesigning OSs (Jenkins and Rickards, 2001). In a review of human factors program implementation in 5 companies, the US General Accounting Office found that, while measurement problems exist, the programs led to increased productivity, decreased absenteeism and injuries, increased quality and increased moral (GAO, 1997). Stanton and Barber (2004) present four cases with payback periods ranging from 1 to 18 weeks and an average savings of $\$ 241,000$ with simple layout changes. Similarly Gustavsen and colleagues (1996), examining 1139 companies from the 
massive Swedish 'Working Life Fund' that funded thousands of workplace development projects found that companies that made more substantial organisational changes (to support good HF), also experienced more substantial productivity growth. Another aspect of the healthproductivity interactions is the concept of 'sickness presenteeism' which refers to those productivity losses occurring before an operator goes on sickness absence. In the construction industry, for example, affected workers reported losing 2 hours productivity work per day on average before leaving work due to the injury (Meerding et al., 2005).

It appears that there is convincing evidence that when designing the operations system according to HF principles, it is likely to have joint positive human and system effects. Theorists have discussed this in terms of the 'convergence' of quality of work life and competitiveness (Huzzard, 2003), and Dul and Put (2010) suggest, based on a study amongst cost leader manufacturing firms, that the application of HF in OS design is a necessary but not sufficient condition for cost leadership, for firms that rely both on humans and technology. The presence of counter examples suggests this relationship might be complex and warrants further examination. Time aspects, crucial for both productivity and ergonomics (Wells et al., 2007), require further study as trade-offs may occur in short term productivity gains reaped by having operators work faster, which are eroded as costs related to injuries and absenteeism begin to cause extra costs and disturbances in production. Studies of the specific combinations of types of design/human effects/system effects are needed as well as investigations of the dynamics of these effects over time (e.g. longitudinal studies).

\subsection{Human Factors and new technology implementation performance}

We found only four studies (9\%) in this category that suggest smoother implementations are available when the new system also has better human outcomes. The study of Udo and Ebiefung (1999) provided the clearest example of the linkage between HF and the success of 
new implementation of advanced manufacturing technologies. Victor et al. (Victor et al., 2000) also showed HF to be an important aspect in successful implementation of TQM management approaches.

It is suggested that the benefits of IT seem to come less from the investment in technology itself than the ability of employees to use the systems in effective ways (Sigala, 2003) - a view consistent with the RBV of the firm (Barney, 1991). Failing to account for HF appropriately in new technology implementation can result in underperformance of the new system and the disappearance of anticipated financial gains, which has been referred to as 'phantom profits' (Neumann, 2004). In the early 1990s, many companies invested in new information technology (IT), but research was unable to show financial benefits of this broad investment. This socalled 'productivity paradox' suggests the need to attend to human aspects in implementation if the benefits of new technologies are to be realised in practice (Badham et al., 1995; Johansson et al., 1993; Stanton and Baber, 2003). A similar trend was observed in early adoption of robotic assembly approaches (Helander, 2006). In the manufacturing sector, international surveys have shown that companies have generally poor to moderate success in applying 'modern manufacturing processes’ (Clegg et al., 2002). A four-year follow-up of the UK sample from this survey showed a consistent increase in implementation success over earlier levels (Wood et al., 2004). This suggests that the companies are learning to overcome weaknesses in the original design or implementation of these techniques to realise their benefits. Research on the process of implementing advanced manufacturing technology has found human factors to be critical to the technical, manufacturing and business success of the implementation (Efstathiades et al., 2002). Similarly, human and organisational factors have been seen as central to the implementation of cellular manufacturing (Park and Han, 2002), IT system implementation (Kerr et al., 2008), “Advanced Manufacturing’ Technologies (Cordero et al., 2008), and (consistent with Victor et al. 2000) TQM implementation (Cheng and Chan, 
1999; Detert et al., 2000). We argue that it is through attention to HF that companies can move beyond the 'fad' of a given technology to reach a 'fit' that produces positive results as seen in the quality area (Van der Wiele et al., 2000). Mital \& Pennathur (2004), in their analysis of 'advanced manufacturing technologies' adoption came to the "obvious but critical conclusiontechnology and humans in modern manufacturing environments are interdependent” (p310) and that humans play a critical role not just in operating, but in overcoming the limitations of a particular technology. One implication of this is that the value of a firms human resources will increases as collective learning learns to leverage new technologies (Yeung et al., 2007).

While the studies in our sample are consistent with the available theoretical literature emphasizing the importance of HF in technology implementation, clearly more research is needed to avoid the design of technologies that do not meet the needs of users and are therefore difficult to leverage successfully as they do not meet the needs of their users. Studies using available usability evaluation methodologies and tracking the success of various implementations may be particularly useful starting points for further research here.

\subsection{Human Factors and intangible effects}

We found 8 studies (18\%) which mention 'intangible' benefits with application of HF in OS design. Intangible benefits that were noted in our dataset include: improved communications (Tjosvold, 1998), improved employee morale (Hull and Azumi, 1988) and improved industrial relations (Lanoie, 1996). It is difficult to separate some intangible effects due to conceptual overlap between system and human effect domains. For example, improved communication (as system effect) and employee 'attitude' (as a human effect) may be interrelated. Furthermore, Lanoie and Tavenas (1996) report difficulties valuing these 'soft' factors. 
Also other intangible effects of HF application in OS design could be expected, such as effects on the reputation of a company (Dul and Neumann, 2009). Good or bad reputation regarding the work environment that can affect, for example, hiring and retention for the firm or goodwill of customers. The value of intangibles, elusive by definition, has been a noted problem for valuing HF efforts (GAO, 1997). Measurement problems notwithstanding, these trends are also consistent with the RBV of the firm and longitudinal panel studies of Tobin's Q and firm performance suggest that intangible factors may contribute to or inhibit future firm profitability (Villalonga, 2004).

Our analysis suggests that designing the operations system according to HF principles could have positive intangible performance effects. Research needs in this domain include improved methodological approaches to valuing intangible elements, as well as a broader understanding of what these various factors are and how they are influenced by OS design. Beyond a larger pool of case studies, longitudinal studies may also be required to understand the impact of these factors over time. Studies such as that by Villalonga (2004) provide a potentially useful model for investigation in this direction.

\subsection{Implications for practice}

The results of our analysis counter the notion that attention to human factors in the design of operations is an expense. Instead, it would appear that careful application of HF principles in the design of operations can improve productivity, quality, technology implementation, and have intangible benefits for operations while also securing well being and working conditions for employees. The results here show that HF is not just a health and safety tool. Unfortunately these potential system gains are not much presented or discussed in the management research literature (see Figure 2). Since few companies measure relevant human effects in their operations, such linkages would not normally emerge in their regular quality improvement 
processes. Without indicators, or without an engineering team well trained in HF, managers must make special efforts to require HF knowledge application in OS design. Managers should require attention to both technical and human aspects in the OS design process as the costs are lowest and availability of solutions are greatest in early phases of design (Alexander, 1998; Miles and Swift, 1998). Since most managers have no education or training in HF (Shikdar and Sawaqed, 2003) this remains a limiter for application - managers require training on how to manage HF in the creation and running of their operations. Managers must learn to see HF as a tool to help achieve excellence in their operations. In an article in Harvard Business Review, Barber and Strack (2005: p.84) emphasize the increased importance of human factors for operations managers: "Success in people intensive business comes from hiring the right people and putting in place processes and an organization that makes them productive ....Line managers have a vital role ...: how to create an organization and work environment that foster productive output. ...People management need to be a core operational process and not solely a support function run by the human resource department”

Another barrier identified by researchers is that the full benefits of HF may take a long time to reap fully (Hantula et al., 2001) - an element of delayed feedback that creates managerial difficulties (Senge, 1990). The organisational changes required to begin capturing the benefits of HF application have been observed to take many years and require ongoing managerial support (Falck, 2009; Neumann, 2004; Smith, 2003; Toulmin and Gustavsen, 1996). We suggest that managers be sceptical of new managerial fads or technologies that have been 'proven' without attention to HF or human effects - and demand evidence of how these approaches include HF. As Udo and Ebiefung (1999: p.300) suggest: “If human factors are ignored in a firm during AMS [advanced manufacturing systems] implementation, there is a good chance that the workers will be discouraged and reluctant to apply themselves and as such, delays may occur in the production schedules." 


\subsection{Implications for research}

\section{Replication}

While the model presented may appear to be just common sense, such an understanding is not commonly reflected in the traditional system focused or human focused research fields and thus needs to be made explicit in OM (c.f. Boudreau et al., 2003). Due to the limited number and the diversity of studies that we found, we could only draw preliminary and general conclusions. Clearly there is a need for more studies to replicate the results in order to give more confidence to the claim that joint human and system effects can be realized with HF. Future studies could pay more attention to the operationalization of the dependent and independent variables with clear definitions of the concepts and possible standardization of the measures in order to make comparisons between studies possible. This seems particularly needed for the intangible system effects of the application of HF in OS design. Regarding human effect measures we note that most of the studies focussed on the physical workload aspects. Research is needed that include the psychosocial aspects of OS design as well, as these aspects have long been associated with risk of sickness-absence (Hoogendoorn et al., 2000; Karasek et al., 1998).

\section{Specific operations systems}

While this study has demonstrated a strong general linkage between HF and the dual outcomes for human and system, it remains a research issue to unravel these relations in a more specific and therefore useful way. Given the wide range of systems included here this will require many more cases, or more limited focus on OS types, to provide specific 'design rules' for engineers and managers responsible for a particular system. We have limited our analysis and conclusions to manufacturing systems. The trends observed in this study need to be re-examined for other sectors (in particular the service sector) to address the issues of differences and similarities of the effects of HF in OS design for sectors other than manufacturing. 


\section{Complexity}

Most studies simplified the complexity of real life operations systems by considering just direct OS design effects on one or two human effects and one or two system effects, usually in a cross-sectional setting. For deeper understanding it is necessary to add more complexity in the research design. For example, moderators, mediators and control variables could be added in the analysis, so as to address possible interaction effects between firm variables, human effects and system effects, and to control for other causes of human and system effects than OS design. One possible moderating variable at firm level could be firm status before intervention as firms with more room to improve might be more likely to reap the double benefit of HF.

Furthermore, multi-level studies should be employed that could link HF application effects at different levels: operations equipment, workstation, company, or sector. Few of the studies identified in our review addressed the long term effects of applying HF. In our data set, the work of Adler (Adler et al., 1997) provided an example of a longitudinal study of OS development with HF attention. There is a need for longitudinal studies that can tap into the dynamics of the interplay of human and technical aspects in OS design over longer time frames - particularly if the effects of the more 'intangible’ factors are to be better understood. Such studies could also address the ‘chains’ of causal relations (Cole and Wells, 2002; Westlander, 1995), and may shed light on more distant effects such as financial firm performance. Conway and Svenson (2001) suggests that firm level benefits do accrue noticeably over time with HF investment.

\section{Emerging areas}

There is a general call for incorporation of human insights into mathematical OM models, in particular in the emerging field of behavioral operations management (Bendoly 2006, Gino and Pisano, 2008; Larco et al. 2008). To address this call, for the topic discussed here, studies that 
aim to quantify the empirical relationships between OS design and human and system effects are needed in order to be able to integrate these relationships into mathematical OM models and to strengthen the relevance of such models for practical applications. This could help to overcome the observed gap between OM and HF in practice. Also, research could be started focusing on this gap in practice and on how to narrow it, providing useful guidance for operations managers who want to capitalise on HF in their operations.

\section{Co-operation between HF and OM researchers}

Successful research in this area depends on the co-operation between HF researchers and OM researchers, as the research topics that we suggest require expertise from both domains. HF and OM researchers need to work collaboratively, since the research issues span multiple expertise domains. Most of the studies in our review tended to do rigorous evaluation of one effect, with a less rigorous supplemental look at the other effects of interest. Improving study quality, by the collaboration of both OM and HF researchers might yield superior study quality with results that are credible in both domains. High levels of study quality through research collaboration can prevent inter-disciplinary HF-OM research from falling into the gap between research agendas of funding agencies that are often also divided between technical and health foci. While OM textbooks often explicitly include HF in its domain (e.g. Heizer and Render, 2007; Wild, 1995), we would encourage OM researchers to include HF knowledge in OM research. While researcher in the HF field are increasingly interested in correlating human and system effects, without examining how the OS contributes to these outcomes (Kahya, 2007; Layer et al., 2009), we would encourage HF researchers to use OM knowledge and to move beyond correlational analyses, to emphasize the linkages between the HF in OS design choices and their consequences in human and system terms. Integration of HF and OM knowledge will be most useful to those who design and manage operations. 


\section{CONCLUSIONS}

45 empirical papers were identified as studying both human and system effects of manufacturing OS design. Of those with clear directional findings, 95\% were consistent with the proposition that application of HF in operations systems can support improvements on both human and system outcomes. Studies providing counter-examples to the HF proposition suggest this relationship may be complex. System effects observed to be associated with improved HF included improved quality, increased productivity, and improved implementation of new technologies. Improvements to less tangible aspects such as morale or communications were also mentioned as effects of HF application. Human effects included those to health, attitudes, physical workload, safety, and more general quality of working life.

The theoretical framework proposed here can help managers and researchers understand the ongoing influence of HF in operations system performance. Future research into OS design alternatives should include HF aspects as well as both human and system effects. The paucity of data in this area implies an opportunity for research and development in the competitive advantages that appears to be available through the application of HF in the design and management of operations systems. Stronger research designs and evaluation methods, rooted in both HF and OM traditions, are needed to address this complex area. Then collaboration between HF researchers and OM researchers can help to span the gap between OM and HRM. 


\section{REFERENCES}

Abrahamsson, L. (2000) Production economics analysis of investment initiated to improve working environment. Applied Ergonomics, v31(1): 1-7

Adler, P. S., Goldoftas, B. and Levine, D. I. (1997) Ergonomics, employee involvement, and the Toyota production system: A case study of Nummi's 1993 model introduction. Industrial \& Labor Relations Review, v50(3): 416-437

Alexander, D. C. (1998) Strategies for cost justifying ergonomic improvements. IIE Solutions, v30(3): 3035

Axelsson, J. R. C. (2000) Quality and ergonomics: towards successful integration. In Linköping studies in science and technology, Dissertations, 616, University of Linköping, Linköping, pp. 362 s. ([2], 362 s.)

Badham, R., Couchman, P. and Little, S. (1995) Getting smart: Developing an action research approach to the integrated management of technical and organisational innovation. Human Systems Management, v14 91-104

Bao, S., Mathiassen, S. E. and Winkel, J. (1996) Ergonomic effects of a management-based rationalization in assembly work - a case study. Applied Ergonomics, v27(2): 89-99

Barber, F., and Strack, R. (2005). The Surprising Economics of a "People Business". Harvard Business Review, 83 (6): 80-90.

Barney, J. B. (1991) Firm resources and sustained competitive advantage. Journal of Management, v17(1): 99-120

Barney, J. B. and Wright, P. M. (1998) On becoming a strategic partner: The role of human resources in gaining competitive advantage. Human Resource Management, v37(1): 3146

Bendoly, E. and Prietula, M., (2008) In "the zone": The role of evolving skill and transitional 
workload on motivation and realized performance in operational tasks, International Journal of Operations \& Production Mananagement, 28(11-12), 1130-1152.

Boudreau, J., Hopp, W., McLain, J. O. and Thomas, L. J. (2003) On the interface between operations management and human resources management. Manufacturing \& Service Operations Management, v5(3): 179-202

Brassler, A. and Schneider, H. (2001) Valuation of strategic production decisions. International Journal of Production Economics, v69(1): 119-127

Carayon, P., Sainfort, F. and Smith, M. J. (1999) Macroergonomics and total quality management: how to improve quality of working life? International Journal of Occupational Safety and Ergonomics, v5(2): 303-334

Challis, D., Samson, D. and Lawson, B. (2002) Integrated manufacturing, employee and business performance: Australian and New Zealand evidence. International journal of production research, v40(8): 1941-1964

Challis, D., Samson, D. and Lawson, B. (2005) Impact of technological, organizational and human resource investments on employee and manufacturing performance: Australian and New Zealand evidence. International journal of production research, v43(1): 81107

Cheng, T.-K. and Chan, S.-F. F. (1999) Quality motivation in China: humanistic and technological. Total Quality Management, v10(7): 967-978

Clegg, C. W., Wall, T. D., Pepper, K., Stride, C., Woods, D., Morrison, D., Cordery, J., Couchman, P., Badham, R., Kuenzler, C., Grote, G., Ide, W., Takahashi, M. and Kogi, K. (2002) An international survey of the use and effectiveness of modern manufacturing practices. Human Factors and Ergonomics in Manufacturing, v12(2): 171-191

Cole, D. C. and Wells, R. P. (2002) Interventions for Musculoskeletal Disorders in ComputerIntense Office Work: A Framework for Evaluation. Work and Stress, v16(2): 95 - 106 
Conway, H. and Svenson, J. (2001) Musculoskeletal Disorders and Productivity. Journal of Labor Research, v22(1): 29-54

Cook, L. S., Bowen, D. E., Chase, R. B., Dasu, S., Stewart, D. M. and Tansik, D. A. (2002) Human issues in service design. Journal of Operations Management, v20(2): 159-174

Cordero, R., Walsh, S. T. and Kirchoff, B. A. (2008) Organization technologies, AMT and competent workers Exploring relationships with manufacturing performance. Journal of Manufacturing Technology Management, v20(3): 298-313

Dababneh, A. J., Swanson, N. and Shell, R. L. (2001) Impact of added rest breaks on the productiity and well being of workers. Ergonomics, v44(2): 164-174

Dahlén, P. and Bolmsjö, G. S. (1998) Human Factors in the Justification of an Advanced Manufacturing System. International Journal of Human Factors in Manufacturing, v6(2): $147-162$

Dangayach, G. S. and Deshmukh, S. G. (2001) Manufacturing Strategy - Literature review and some issues. International Journal of Operations and Production Management, v21(7): 884-932

De Jong, A. M. V. P. (2002) Participatory Ergonomics Applied in Installation Work. Applied Ergonomics ISSN: 0003-6870, v33(5): 439 - 448

Detert, J. R., Schroeder, R. G. and Mauriel, J. J. (2000) A framework for linking culture and improvement initiatives in organizations. Academy of Management Review, v25(4): 850-863

Dickersin, K. and Min, Y.-I. (1993) Publication Bias: The problem that won't go away. Annals of the New York Academy of Sciences, v703(1): 135-148

Dillard, B. G. and Schwager, T. F. (1997) Ergonomics Equipment investments: benefits to apparel manufacturers. International Journal of Clothing Science and Technology, v9(4): $285-300$ 
Drury, C. G. (2000) Global quality: linking ergonomics and production. International journal of production research, v38(17): 4007-4018

Dul, J. (2003) Ergonomics in Management. In Proceedings of the XVth Triennial Congress of the International Ergonomics Association, 7 The Ergonomics Society of Korea, Seoul, Korea, pp. 5-6.

Dul, J. and Neumann, W. P. (2009) Ergonomics Contributions to Company Strategies. Applied Ergonomics, v40(4): 745-752

Dul, J. and Put, M. (2010) Contributions of Ergonomics to Cost Leadership in Manufacturing. Working Paper. Rotterdam School of Management.

Efstathiades, A., Tassou, S. and Antoniou, A. (2002) Srategic planning, transfer and implementation of advanced manufacturing technologies (AMT). Development of an integrated process plan. Technovation, v22(201-212

Eijnatten, F. M. v., Sitter, U. d., Gustavsen, B., Emery, F. and Beinum, H. v. (1993) The paradigm that changed the work place, Van Gorcum; Arbetslivscentrum, Stockholm. 90-232-2805-7

Eklund, J. A. E. (1995) Relationships between Ergonomics and Quality in Assembly Work. Applied Ergonomics, v26(1): 15-20

Falck, A-C. (2009). Ergonomics Methods and Work Procedures in Car Manufacturing for Improvement of Quality, Productivity and Health at Work, Chalmers University of Technology, Gothenburg, Sweden. ISSN 0346-718X ; 2959. ISBN 978-91-7385-278-4. Doctoral thesis.

Fenton-O'Creeyv, M. (1998) Employee involvement and the middle manager: Evidence from a survey of organizations. Journal of Organizational Behavior, v19(1): 67-84

Fisher, D. L., Andres, R. O., Airth, D. and Smith, S. (1993) Repetitive Motion Disorders: The Design of Optimal Rate-Rest Profiles. Human Factors, v35(2): 283 - 304 
Frick, K. (1994) Från sidovagn till integrerat arbetsmiljöarbete: arbetsmiljöstyrning som ett ledningsproblem i svensk industri, Arbetslivscentrum, Stockholm. 91-86576-25-9

GAO (1997) "Private Sector Ergonomics Programs Yield Positive Results" US General Accounting Office - Health Eductation and Human Services Division.

Getty, R. L. and Getty, J. M. (1999) Ergonomics Oriented to Processes Becomes a Tool for Continuous Improvement. International Journal of Occupational Safety and Ergonomics, v5(2): 161 - 194

Ghobadian, A. and Gallear, D. (2001) TQM implementation: an empirical examination and proposed generic model. Omega, v29(343-359

Gino, F. and Pisano, G., (2008) Toward a Theory of Behavioral Operations. Manufacturing Service Operations Management, 10(4), 676-691.

Godfrey, G., Dale, B., Marchinigton, M. and Wilkinson, A. (2005) Control: a contested concept in TQM research. International journal of operations \& production management, v17(6): 558-573

González, B. A., Adenso-Díaz, B. and González Torre, P. (2003) Ergonomic performance and quality relationship; an empirical evidence case. International journal of industrial ergonomics, v31(1): 33-40

Govindaraju, M., Pennathur, A. and Mital, A. (2001) Quality improvement in manufacturing through human performance enhancement. Integrated Manufacturing Systems, v12/5(360-367

Gustavsen, B., Ekman Philips, M., Wikman, A. and Hofmaier, B. (1996) Concept-driven development and the organization of the process of change : an evaluation of the Swedish working life fund, Benjamins, Amsterdam. 90-272-1773-4

Hagberg, M., Silverstein, B., Wells, R., Smith, R., Carayon, P., Hendrick, H. P., Perusse, M., Kuorinka, I. and Forcier, L. (1995) Work-related Musculoskeletal Disorders (WMSD): A Handbook for Prevention, Taylor and Francis, London. 
Hägg, G. M. (2003) Corporate initiatives in ergonomics - an introduction. Applied Ergonomics, v34(1): 3-15

Halpern, C. A. and Dawson, K. D. (1997) Design and implementation of a participatory ergonomics program for machine sewing tasks. International journal of industrial ergonomics, v20(6): 429-440

Hantula, D. A., Rajala, A. K., Kellerman, E. G. B. and Bragger, J. L. D. (2001) The value of workplace safety: A time-based utility analysis model. Journal of Organizational Behavior Management, v21(2): 79-98

Harms-Ringdahl, L. (1990) On Economic Evaluation of Systematic Safety Work at Companies. Journal of Occupational Accidents, v12(1 - 3): 89 - 98

Harter, S. P. (1986) Online information retrieval: concepts, principles, and techniques, Acadmic Press, Orlando. 0123284554

Heizer, J. and Render, B. (2007) Operations Management, Prentice Hall, London. 9780138128784

Helander, M. (2006) A Guide to Human Factors and Ergonomics 2nd ed., Taylor \& Francis, Toronto. 0-415-28248-9

Helander, M. G. and Burri, G. J. (1995) Cost Effectiveness of Ergonomics and Quality Improvements in Electronics Manufacturing. International Journal of Industrial Ergonomics ISSN: 0169-8141, v15(2): 137 - 151

Hendrick, H. W. (2003) Determining the cost-benefits of ergonomics projects and factors that lead to their success. Applied Ergonomics, v34(5): 419-427

Hignett, S., Wilson, J. R. and Morris, W. (2005) Finding ergonomic solutions - participatory approaches. Occupational Medicine-Oxford, v55(3): 200-207

Hull, F. and Azumi, K. (1988) Technology and Participation in Japanese Factories. Work \& Occupations, v15(4): 423-448 
Hunter, S. L., Bullard, S. and Steele, P. H. (2004) Lean production in the furniture industry: The double D assembly cell. Forest Products Journal, v54(4): 32-38

Huzzard, T. (2003) "The convergence of the quality of working life and competitiveness - A current Swedish literature review" Ekstedt, E. Work life in transition. National Insitute for Working Life.

IEA Council (2000) The Discipline of Ergonomics. International Ergonomics Society, pp. 1. http://www.iea.cc/browse.php?contID=what_is_ergonomics

Ingelgård, A. and Norrgren, F. (2001) Effects of change strategy and top-management involvement on quality of working life and economic results. International journal of industrial ergonomics, v27(2): 93-105

James, D., Grennan, S. and Mulhern, G. (1994) Ergonomics in Northern-Ireland - a Survey of Knowledge, Attitudes, and Implementation in Industry and the Public-Services. Ergonomics, v37(5): 953-963

Jenkins, S. and Rickards, J. (2001) "The economics of ergonomics: three workplace design case studies" In Alexander, D. C. and Rabourn, R. (Ed.) Applied Ergonomics, Taylor \& Francis, London, pp. 336. 0-415-23852-8

Jensen, P. L. (2001) Risk assessment: a regulatory strategy for stimulating working environment activities? Human Factors and Ergonomics in Manufacturing, v11(2): $101-116$

Johansson, J. Å., Kadefors, R., Rubenowitz, S., Klingenstierna, U., Lindström, I., Engström, T. and Jahansson, M. (1993) Musculoskeletal symptoms, ergonomic aspects and psychosocial factors in two different truck assembly concepts. InternationalJjournal of Industrial Ergonomics, v12(35-48

Juran, D. C. and Schruben, L. W. (2004) Using worker personality and demographic information to improve system performance prediction. Journal of Operations Management, v22(355-367 
Kahya, E. (2007) The effects of job characteristics and working conditions on job performance. International journal of industrial ergonomics, v37(6): 515-523

Karasek, R. and Theorell, T. (1990) Healthy Work. Stress Productivity, and Reconstruction of Working Life, Basic Books Inc., New York. 0-465-02897-7

Kazmierczak, K., Neumann, W. P. and Winkel, J. (2007) A case study of serial-flow car disassembly: ergonomics, productivity, and potential system performance. Human Factors and Ergonomics in Manufacturing, v17(4): 331-351

Kerr, M. P., Knott, D. S., Moss, M. A., Clegg, C. W. and Horton, R. P. (2008) Assessing the value of human factors initiatives. Applied Ergonomics, v39(3): 305-315

Klatte, T., Daetz, W. and Laurig, W. (1997) Quality improvement through capable processes and ergonomic design. International journal of industrial ergonomics, v20(399-411

Kleiner, B. M. (1999) Macroergonomic analysis and design for improved saftey and quality performance. International Journal of Occupational Safety and Ergonomics, v5(2): $217-245$

Koningsveld, E. A. P. (2003) Indicators That Convince Management, Workers, and Supporting Departments. Human Factors in Organizational Design and Management - VII. ReDesigning Work and Macroergonomics - Future Perspectives and Challenges, Edited by H. Luczak and K.J. Zink. IEA Press, Santa Monica, California, 753 - 756

Lahiri, S., Gold, J. and Levenstein, C. (2005) Net-cost model for workplace interventions. Journal of Safety Research, v36(3): 241-55

Lanoie, P. and Tavenas, S. (1996) Costs and Benefits of Preventing Workplace Accidents: The Case of Participatory Ergonomics. Safety Science ISSN: 0925-7535, v24(3): 181 - 196

Larco, J.A., Roodbergen, K.J., De Koster, M.B.M., and Dul, J. (2008) Optimizing order picking considering workers’ comfort and picking speed. In: Progress in Material Handling Research: 2008. K. Ellis et al. (eds), Material Handling Institute Charlotte, North Carolina, 467-478 
Layer, J. K., Karwowski, W. and Furr, A. (2009) The effect of cognitive demands and perceived quality of work life on human performance in manufacturing environments. International journal of industrial ergonomics, v39(2): 413-421

Lee, K. S. (2005) Ergonomics in total quality management: How can we sell ergonomics to management? Ergonomics, v48(5): 547-558

Leigh, J. P., Markowitz, S. B., Fahs, M., Shin, C. and Landrigan, P. J. (1997) Occupational injury and illness in the United States. Estimates of costs, morbidity, and mortality. Arch Intern Med, v157(14): 1557-68

Lin, L., Drury, C. G. and Kim, S. W. (2001) Ergonomics and Quality in Paced Assembly Lines. Human Factors and Ergonomics in Manufacturing, v11(4): 377 - 382

Loeppke, R., Taitel, M., Richling, D., Parry, T., Kessler, R. C., Hymel, P. and Konicki, D. (2007) Health and productivity as a business strategy. Journal of Occupational and Environmental Medicine, v49(7): 712-721

de Looze, M. P., van Rhin, J. W., van Deursen, J., Tuinzaad, G. H. and Reijneveld, C. N. (2003) A participatory and integrative approach to improve productivity and ergonomics in assembly. Production Planning \& Control, v14(2): 174-181

Lutz, T. J., Starr, H., Smith, C. A., Stewart, A. M., Monroe, M. J., Joines, S. M. B. and Mirka, G. A. (2000) Technical Note: The use of mirrors during an assembly task: a study of ergonomics and productivity. Ergonomics, v44(2): 215-228

Meerding, W. J., IJzelenberg, W., Koopmanschap, M. A., Severens, J. L. and Burdorf, A. (2005) Health problems lead to considerable productivity loss at work among workers with high physical load jobs. Journal of Clinical Epidemiology, v58(5): 517-523

Miles, B. L. and Swift, K. (1998) Design for manufacture and assembly. Manufacturing Engineer, v77(5): 221-224 
Mital, A. and Pennathur, A. (2004) Advanced technologies and human in manufacturing workplaces: an interdependent relationship. International journal of industrial ergonomics, v33(2004

Morag, I. (2007) Intel's incident-free culture: A case study. Applied Ergonomics, v38(2): 201211

Moreau, M. (2003) Corporate ergonomics programme at automobiles Peugeot-Sochaux. Applied Ergonomics, v34(29-34

Motamedzade, M., Shahnavaz, H., Kazemnejad, A., Azar, A. and Karimi, H. (2003) The Impact of Participatory Ergonomics on Working Conditions, Quality, and Productivity. International Journal of Occupational Safety and Ergonomics, v9(2): 135 - 147

National Research Council (2001) Musculoskeletal Disorders in the Workplace - Low Back and Upper Extremities, National Academy Press, Washington DC. 0-309-07284-0

Neumann, W. P., Kihlberg, S., Medbo, P., Mathiassen, S. E. and Winkel, J. (2002) A case study evaluating the ergonomic and productivity impacts of partial automation strategies in the electronics industry. International journal of production research, v40(16): 40594075

Neumann, W. P. (2004) Production Ergonomics: Identifying and managing risk in the design of high performance work systems. In Design Sciences, PhD Thesis Lund Technical University, Lund, pp. 159. www.ryerson.ca/hfe

Neumann, W. P., Winkel, J., Medbo, L., Magneberg, R. and Mathiassen, S. E. (2006) Production system design elements influencing productivity and ergonomics - A case study of parallel and serial flow strategies. International journal of operations \& production management, v26(8): 904-923

Oxenburgh, M., Marlow, P. and Oxenburgh, A. (2004) Increasing productivity and profit through health \& safety : the financial returns from a safe working environment, CRC Press, Bocka Raton, Fla. 0-415-24331-9 
Oxenburgh, M. and Marlow, P. (2005) The Productivity Assessment Tool: Computer-based cost benefit analysis model for the economic assessment of occupational health and safety interventions in the workplace. Journal of Safety Research, v36(3): 209-214

Parenmark, G., Malmkvist, A. K. and Örtengren, R. (1993) Ergonomic Moves in an Engineering Industry. Effects on Sickleave, Labour Turnover and Productivity through Ergonomic Intervention. International journal of industrial ergonomics, v11(4): 291300

Park, K. S. and Han, S. W. (2002) Performance obstacles in cellular manufacturing - Empirical Investigation. Human Factors and Ergonomics in Manufacturing, v12(1): 17-29

Park, S., Hartley, J. L. and Wilson, D. (2001) Quality management practices and their relationships to buyer's supplier ratings: a study in the Korean automotive industry. Journal of Operations Management, v19(6): 695-712

Pfeffer, J. (1994) Competitive Advantage Through People. California Management Review, vWinter(1994;36,2): 9-28

Prahalad, C. K. (2004) The Blinders of Dominant Logic. Long Range Planning, v37(171-179

Reason, J. (1990) The contribution of latent human failures to the breakdown of complex systems. Philosophical Transactions of the Royal Society Of London. Series B: Biological Sciences, v327(1241): 475-484

Rhijn, J. W. v., Looze, M. P. d. and Tuinzaad, G. (2005) Changing from batch flow assembly in the production of ermergency lighting devices. International journal of production research, v43(3687-3701):

Salzmann, O., Ionescu-Somers, A. and Steger, U. (2005) The Business Case for Corporate Sustainability: Literature Review and Research Options. European Management Journal, v23(1): 27-36

Seeley, P. A. and Marklin, R. W. (2003) Business case for implementing two ergonomic interventions at an electric power utility. Applied Ergonomics, v34(5): 429-439 
Sen, R. N. and Yeow, P. H. P. (2003) Cost effectiveness of ergonomic redesign of electronic motherboard. Applied Ergonomics, v34(5): 453-463

Senge, P. M. (1990) The Fifth Discipline - The Art \& Practice of the Learning Organisation, Century Business, London. 0-7126-5687-1

Shikdar, A. A. and Das, B. (2003) A strategy for improving worker satisfaction and job attitudes in a repetitive industrial task: application of production standards and performance feedback. Ergonomics, v46(5): 466-481

Shikdar, A. A. and Sawaqed, N. M. (2003) Worker productivity, and occupational health and safety issues in selected industries. Computers \& Industrial Engineering, v45(4): 563572

Shipton, H. J., West, M. A., Parkes, C. L. and Dawson, J. F. (2006) When promoting positive feelings pays: Aggregate job satisfaction, work design features, and innovation in manufacturing organizations. European Journal of Work and Organisational Psychology, v15(4): 404-430

Sigala, M. (2003) The information and communication technologies productivity impact on the UK hotel sector. International journal of operations \& production management, v23(10): 1224-1245

Smith, M. J. and Bayehi, A. D. (2003) Do ergonomics improvements increase computer workers' productivity?: an intervention study in a call centre. Ergonomics, v46(1-3): 318

Smith, R. T. (2003) Growing an ergonomics culture in manufacturing. Proceedings of the Institution of Mechanical Engineers Part B-Journal of Engineering Manufacture, v217(7): 1027-1030

Smith, T. J. (1999) Synergism of Ergonomics, Safety, and Quality - a Behavioral Cybernetic Analysis. International Journal of Occupational Safety and Ergonomics, v5(2): 247 278 
Stanton, N. A. and Baber, C. (2003) Editorial: On the cost-effectiveness of ergonomics. Applied Ergonomics, v34(5): 407-411

Stanton, N. A., Hedge, A., Brookhuis, K., Salas, E. and Hendrick, H. (2004) Handbook of human factors and ergonomics methods, CRC Press, London. 0-415-28700-6

Sundin, A., Christmansson, M. and Larsson, M. (2004) A different perspective in participatory ergonomics in product development improves assembly work in the automotive industry. International journal of industrial ergonomics, v33(1): 1-14

Tari, J. J. and Sabater, V. (2006) Human aspects in a quality management context and their effects on performance. International Journal of Human Resource Management, v17(3): 484-503

Tjosvold, D. (1998) Making Employee Involvement Work: Cooperative Goals and Controversy to Reduce Costs. Human Relations, v51(2): 201-214

Torgerson, C. J. (2006) Publication Bias: The Achilles' heel of systematic reviews. British Journal of Educational Studies, v54(10): 89-102

Toulmin, S. E. and Gustavsen, B. (1996) Beyond Theory : Changing organizations through participation, John Benjamins Publ., Philadelphia, Penn. ; Amsterdam. 90-272-1772-6

Udo, G. G. and Ebiefung, A. A. (1999) Human factors affecting the success of advanced manufacturing systems. Computers \& Industrial Engineering, v37(1/2): 297-300

Van der Wiele, A., Dale, B. G. and Williams, A. R. T. (2000) ISO9000 Series and Ecellence Models: Fad to Fashion to Fit. Journal of General Management, v25(3): 50-67

Vi, P. (2006) A field study investigating the effects of a rebar-tying machine on trunk flexion, tool usability and productivity. Ergonomics, v49(14): 1437 - 1455

Victor, B., Boynton, A. and Stephens-Jahng, T. (2000) The Effective Design of Work Under Total Quality Management. Organization Science: A Journal of the Institute of Management Sciences, v11(1): 102-116 
Villalonga, B. (2004) Intangible resources, Tobin's q, and sustainablity of performance differences. Journal of Economic Behavior \& Organization, v54(205-230

Walsh, J. P., Weber, K. and Margolis, J. D. (2003) Social issues and management: our lost cause found. Journal of Management, v29(6): 859-881

Weber, M. (2008) The business case for corporate social responsibility: a company-level measurement approach for CSR. European Management Journal, v26(4): 247-261

Wells, R., Mathiassen, S. E., Medbo, L. and Winkel, J. (2007) Time - a key issue for musckuloskeletal health and manufacturing. Applied Ergonomics, v38(6): 733-744

Westlander, G. (1995) Means, goals, and outcome of a comprehensive occupational health program for telephone operators. International Journal of Health Services, v25(2): 313332

WHO (1999) "Fact Sheet \#84: Occupational Health - ethically correct, economically sound" World Health Organisation. http://www.who.int/en/

Wild, R. (1995) Production and Operations Management: Text and Cases. 5th ed., Cassell, London. 0-304-33077-9

Wirojanagud, P., Gel, E. S., Fowler, J. W. and Cardy, R. (2007) Modelling inherent worker differences for workforce planning. International journal of production research, v45(3): 525-553

Wood, S. J., Stride, C. B., Wall, T. D. and Clegg, C. W. (2004) Revisiting the use and effectiveness of modern management practices. Human Factors and Ergonomics in Manufacturing, v14(4): 415-432

Wright, T. A. and Cropanzano, R. (2004) The Role of Psychological Well-Being in Job Performance: A Fresh Look at an Age-Old Quest. Organizational Dynamics Organizational Dynamics J1 - Organizational Dynamics, v33(4): 338-351 
Yee, R. W. Y., Yeung, A. C. L. and Cheng, T. C. E. (2008) The impact of employee satisfaction on quality and profitability in high-contact service industries. Journal of Operations Management, v26(5): 651-668

Yeow, P. H. P. and Sen, R. N. (2003) Quality, productivity, occupational health and safety and cost effectiveness of ergonomic improvements in the test workstations of an electronic factory. International journal of industrial ergonomics, v32(147-163

Yeow, P. H. P. and Sen, R. N. (2004) Ergonomics Improvements of the Visual Inspection Process in a Printed Circuit Assembly Factory. International Journal of Occupational Safety and Ergonomics, v10(4): 369 - 385

Yeow, P. H. P. and Sen, R. N. (2006) Productivity and quality improvements, revenue increment, and rejection cost reduction in the manual component insertion lines through the application of ergonomics. International journal of industrial ergonomics, v36(4): $367-377$

Yeung, A. C. L., Lai, K.-H. and Yee, R. W. Y. (2007) Organizational learning, innovativeness, and organizational performance: a qualitative investigation. International journal of production research, v45(11): 2459-2477 


\section{FIGURES}

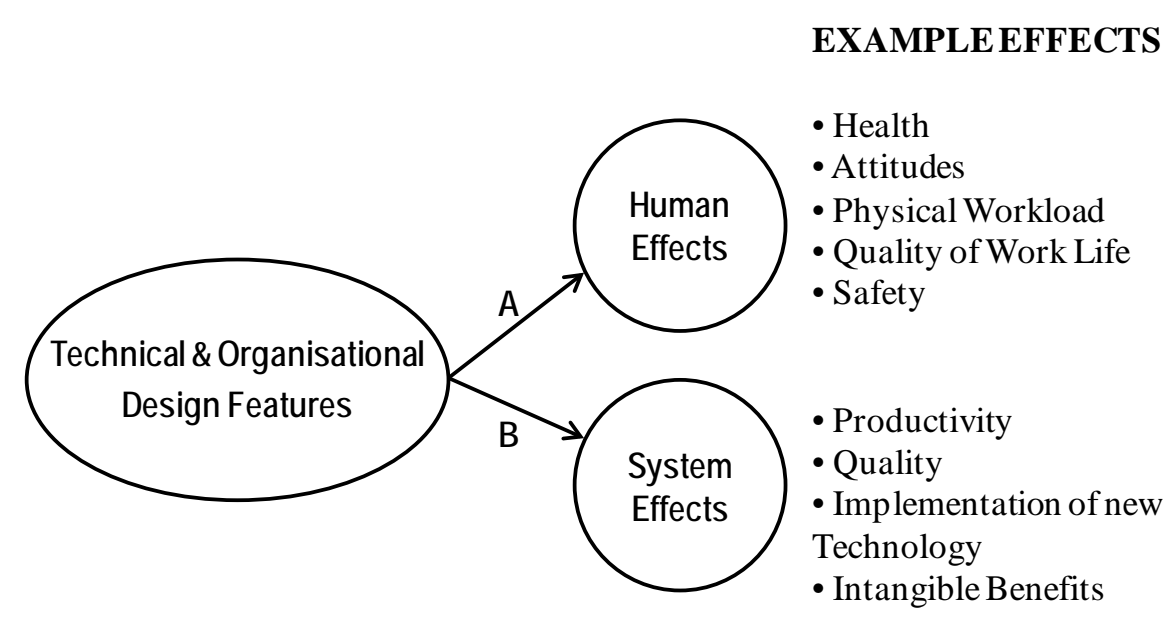

Figure 1: A simple framework illustrating how the technical and organisational features of the operations system have both human effects (e.g. physical workload) and system effects (e.g productivity). 


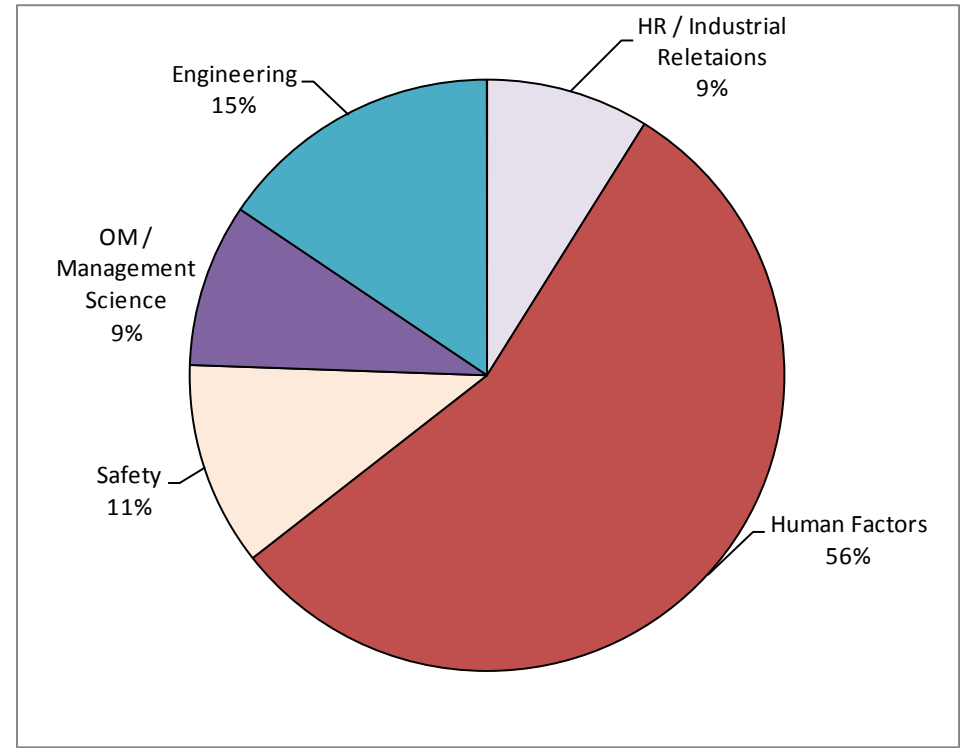

Figure 2: Relative distribution of articles by discipline 


\section{TABLES}

Table 1: Matrix relating possible effects of operations system design choices on humans and the system.

\begin{tabular}{|c|c|c|c|}
\cline { 3 - 3 } \multicolumn{2}{c|}{} & \multicolumn{2}{c|}{ Human effects } \\
\cline { 3 - 4 } \multicolumn{2}{c|}{} & Negative & Positive \\
\hline \multirow{2}{*}{ System effects } & Negative & I (lose-lose) & II (lose-win) \\
\cline { 2 - 4 } & Positive & III (win-lose) & IV (win-win) \\
\hline
\end{tabular}


Table 2: Examples of search terms used in the systematic search of three scientific databases

\begin{tabular}{|l|l|}
\hline Search terms to identify papers with & Search terms to identify papers with \\
possible Human Effects indicators. & possible System Effects indicators \\
\hline Ergonomics & Business strategy \\
Health & Corporate strategy \\
Applied ergonomics & Management involvement \\
Engineering & Leadership \\
Occupational health & Top management \\
Occupational safety & TQM (and variations) \\
Quality of working life & Safety management \\
Human factors & Operations management \\
Occupational diseases & Industrial engineering \\
Industrial safety & Business \\
Work environment & Manufacturing \\
Safety & Manufacturing processes \\
Social goals & Industrial efficiency \\
Participation & Industrial productivity \\
Commitment & Labor productivity \\
Motivation & Production management \\
Introduction of ergonomics (EA) & Industrial management \\
Work design and organisation for health & Business planning \\
and safety (EA) & Strategic planning \\
Effects on the musculo-skeletal system & Cost \\
(EA) & Cost benefit (analysis) \\
Workload & Executives \\
Workload demands & Performance \\
Posture & Just-in-time systems \\
Job enrichment & Introduction and strategies for introduction \\
Marketing of ergonomics (EA) & of change (EA) \\
\hline EA terms particular to the Ergonomics Abstrats database \\
\hline
\end{tabular}

EA = terms particular to the Ergonomics Abstracts database. 
Table 3: Types of human effects included in the identified pool studies ( $n=45$, some studies included more than one type of factor listed here, resulting in greater than $100 \%$ total).

\begin{tabular}{|l|r|r|}
\hline Human effects & \# studies & \% of studies \\
\hline Health & 18 & $40 \%$ \\
\hline Attitudes & 13 & $29 \%$ \\
\hline Physical Workload & 28 & $62 \%$ \\
\hline QWL & 5 & $11 \%$ \\
\hline Safety & 5 & $11 \%$ \\
\hline Employee Performance & 1 & $2 \%$ \\
\hline \multicolumn{3}{|c|}{} \\
\hline System effects & 40 & $89 \%$ \\
\hline Productivity & 14 & $31 \%$ \\
\hline Quality & 4 & $9 \%$ \\
\hline Implementation & 8 & $18 \%$ \\
\hline Intangibles & \# Studies & of Studies \\
\hline
\end{tabular}


Table 4: Results of the 2x2 classification studies according to human and system effects $(n=38)$.

\begin{tabular}{|c|c|c|c|}
\hline & & \multicolumn{2}{|c|}{$\begin{array}{c}\text { Human effects } \\
\text { \# papers }(\%)\end{array}$} \\
\hline & & Negative & Positive \\
\hline \multirow{2}{*}{$\begin{array}{l}\text { System } \\
\text { effects }\end{array}$} & Negative & $3(7.9 \%)$ & $1(2.6 \%)$ \\
\hline & Positive & $1(2.6 \%)$ & $33(86.8 \%)$ \\
\hline
\end{tabular}


Table 5: Summary of research addressing both human and system effects in operations systems sorted alphabetically by first author. The nature of the study (e.g. 'case study of redesign') is stated along with the journal name, the human effect, the system effect. The Results include a direction of human and system effects, respectively as 'Win', 'Lose', 'Null' or 'Complex'.

\begin{tabular}{|c|c|c|c|c|}
\hline $\begin{array}{l}\text { Reference } \\
\text { - Study } \\
\text { description }\end{array}$ & Journal & $\begin{array}{c}\text { Human } \\
\text { Effect }\end{array}$ & $\begin{array}{c}\text { System } \\
\text { Effect }\end{array}$ & Results \\
\hline $\begin{array}{l}\text { (Abrahamsson, } \\
2000) \\
\text { - Case study of } \\
\text { re-design in a } \\
\text { foundry for } \\
\text { improved work } \\
\text { environment }\end{array}$ & $\begin{array}{l}\text { Applied } \\
\text { Ergonomics }\end{array}$ & $\begin{array}{l}\text { Health, } \\
\text { Workload, } \\
\text { Quality of Work } \\
\text { Life }\end{array}$ & $\begin{array}{l}\text { Productivity, } \\
\text { Quality \& } \\
\text { Intangibles }\end{array}$ & $\begin{array}{l}\text { HF investment yields ROI } \\
\text { of } 2.2 \text { in direct benefits } \\
\text { (WIN - WIN) }\end{array}$ \\
\hline $\begin{array}{l}\text { (Adler et al., } \\
\text { 1997) } \\
\text { - Longitudinal } \\
\text { case study of } \\
\text { introduction new } \\
\text { car model in } \\
\text { production }\end{array}$ & $\begin{array}{l}\text { Industrial \& } \\
\text { Labor } \\
\text { Relations } \\
\text { Review }\end{array}$ & Health & Productivity & $\begin{array}{l}\text { Good design can improve } \\
\text { both employee health and } \\
\text { profitability } \\
\text { (COMPLEX) }\end{array}$ \\
\hline $\begin{array}{l}\text { (Bao et al., 1996) } \\
\text { - Intervention } \\
\text { study aiming to } \\
\text { reduce physical } \\
\text { workload }\end{array}$ & $\begin{array}{l}\text { Applied } \\
\text { Ergonomics }\end{array}$ & Workload & Productivity & $\begin{array}{l}\text { Product redesign reduces } \\
\text { assembly time to } 52 \% \\
\text { without increased risk to } \\
\text { operators. } \\
\text { (NULL - WIN) }\end{array}$ \\
\hline $\begin{array}{l}\text { (Challis et al., } \\
\text { 2002) (Challis et } \\
\text { al., 2005) } \\
\text { - Survey of } 1289 \\
\text { firms in Australia } \\
\text { and New Zealand. }\end{array}$ & $\begin{array}{l}\text { International } \\
\text { Journal of } \\
\text { Production } \\
\text { Research }\end{array}$ & $\begin{array}{l}\text { Employee } \\
\text { Performance }\end{array}$ & $\begin{array}{l}\text { Productivity \& } \\
\text { Implementation }\end{array}$ & $\begin{array}{l}\text { Employee performance and } \\
\text { manufacturing performance } \\
\text { correlate - particularly in } \\
\text { advanced manufacturing } \\
\text { technology environments. } \\
\text { (WIN - WIN) }\end{array}$ \\
\hline $\begin{array}{l}\text { (Conway and } \\
\text { Svenson, 2001) } \\
\text { - Analysis of } \\
\text { Bureau of labour } \\
\text { statistics } \\
\text { databases }\end{array}$ & $\begin{array}{l}\text { Journal of } \\
\text { Labour } \\
\text { Research }\end{array}$ & Health & Productivity & $\begin{array}{l}\text { Better HF related to faster } \\
\text { productivity improvements } \\
\text { (WIN - WIN) }\end{array}$ \\
\hline $\begin{array}{l}\text { (Dababneh et al., } \\
2001) \\
\text { - Study of use of } \\
\text { extra rest breaks } \\
\end{array}$ & Ergonomics & Health & Productivity & $\begin{array}{l}\text { Additional rest breaks } \\
\text { reduced discomfort without } \\
\text { reducing productivity } \\
\text { (WIN - NULL) }\end{array}$ \\
\hline $\begin{array}{l}\text { (Dahlén and } \\
\text { Bolmsjö, 1998) } \\
\text { - Case study in a } \\
\text { Swedish } \\
\text { engineering firm }\end{array}$ & $\begin{array}{l}\text { International } \\
\text { Journal of } \\
\text { Human } \\
\text { Factors in } \\
\text { Manufacturing }\end{array}$ & Workload & Productivity & $\begin{array}{l}\text { Automation of repetitive } \\
\text { monotonous work improves } \\
\text { performance and yields } \\
\text { better HF for employees } \\
\text { (WIN - WIN) }\end{array}$ \\
\hline
\end{tabular}




\begin{tabular}{|c|c|c|c|c|}
\hline $\begin{array}{l}\text { Reference } \\
\text { - Study } \\
\text { description }\end{array}$ & Journal & $\begin{array}{c}\text { Human } \\
\text { Effect }\end{array}$ & $\begin{array}{c}\text { System } \\
\text { Effect }\end{array}$ & Results \\
\hline $\begin{array}{l}\text { (De Jong, 2002) } \\
\text { - Intervention } \\
\text { study of } \\
\text { 'participatory } \\
\text { ergonomics' in } \\
\text { installation work }\end{array}$ & $\begin{array}{l}\text { Applied } \\
\text { Ergonomics }\end{array}$ & Workload & Productivity & $\begin{array}{l}\text { HF improvements yield ROI } \\
\text { of } 1 \text { year } \\
\text { (WIN - WIN) }\end{array}$ \\
\hline $\begin{array}{l}\text { (De Looze et al., } \\
2003 \text { ) } \\
\text { - Case study of } \\
\text { assembly system } \\
\text { re-design }\end{array}$ & $\begin{array}{l}\text { Production } \\
\text { Planning and } \\
\text { Control }\end{array}$ & Workload & Productivity & $\begin{array}{l}\text { Applying HF reduced risk } \\
\text { and improved productivity } \\
15-20 \% \\
\text { (WIN - WIN) }\end{array}$ \\
\hline $\begin{array}{l}\text { (Eklund, 1995) } \\
\text { - Case study of } \\
\text { quality deficits in } \\
\text { assembly }\end{array}$ & $\begin{array}{l}\text { Applied } \\
\text { Ergonomics }\end{array}$ & $\begin{array}{l}\text { Workload \& } \\
\text { Attitudes }\end{array}$ & $\begin{array}{l}\text { Quallity \& } \\
\text { Intangibles }\end{array}$ & $\begin{array}{l}\text { HF deficits related to quality } \\
\text { deficits and reduced job } \\
\text { satisfaction } \\
\text { (LOSE - LOSE) }\end{array}$ \\
\hline $\begin{array}{l}\text { (Fenton- } \\
\text { O'Creeyv, 1998) } \\
\text { - Survey of 114 } \\
\text { companies using } \\
\text { employee } \\
\text { involvement } \\
\text { practices. }\end{array}$ & $\begin{array}{l}\text { Journal of } \\
\text { Organisational } \\
\text { Behaivior }\end{array}$ & Attitudes & $\begin{array}{l}\text { Productivity \& } \\
\text { Intangibles }\end{array}$ & $\begin{array}{l}\text { Employee involvement } \\
\text { improves both attitudes and } \\
\text { performance. } \\
\text { (WIN - WIN) }\end{array}$ \\
\hline $\begin{array}{l}\text { (Fisher et al., } \\
\text { 1993) } \\
\text { Simulation study } \\
\text { of work-rest } \\
\text { scheduling in } \\
\text { repetitive } \\
\text { manufacturing } \\
\text { work }\end{array}$ & $\begin{array}{l}\text { Human } \\
\text { Factors }\end{array}$ & Workload & Productivity & $\begin{array}{l}\text { It is possible to maximise } \\
\text { performance within lower } \\
\text { risk system profiles } \\
\text { (WIN - WIN) }\end{array}$ \\
\hline $\begin{array}{l}\text { (Getty and Getty, } \\
\text { 1999) } \\
\text { - Case overview } \\
\text { of process with } \\
\text { specific } \\
\text { ergonomics } \\
\text { examples from } \\
\text { Lockheed Martin }\end{array}$ & $\begin{array}{l}\text { International } \\
\text { Journal of } \\
\text { Occupational } \\
\text { Safety and } \\
\text { Health }\end{array}$ & $\begin{array}{l}\text { Health Status \& } \\
\text { Workload }\end{array}$ & $\begin{array}{l}\text { Productivity \& } \\
\text { Implementation }\end{array}$ & $\begin{array}{l}\text { Applying HF is a } \\
\text { competitive advantage with } \\
\text { ROIs as low as } 6 \text { weeks } \\
\text { (WIN - WIN) }\end{array}$ \\
\hline $\begin{array}{l}\text { (Harms-Ringdahl, } \\
\text { 1990) } \\
\text { - Four case } \\
\text { studies of safety } \\
\text { interventions }\end{array}$ & $\begin{array}{l}\text { Journal of } \\
\text { Occupational } \\
\text { Accidents }\end{array}$ & $\begin{array}{l}\text { Health Status \& } \\
\text { Safety }\end{array}$ & Productivity & $\begin{array}{l}\text { Safety interventions' main } \\
\text { economic benefit is on the } \\
\text { production side. } \\
\text { (WIN - WIN) }\end{array}$ \\
\hline $\begin{array}{l}\text { (Helander and } \\
\text { Burri, 1995) } \\
\text { - Overview of four } \\
\text { cases of } \\
\text { ergonomics } \\
\text { redesign at IBM }\end{array}$ & $\begin{array}{l}\text { International } \\
\text { Journal of } \\
\text { Industrial } \\
\text { Ergonomics }\end{array}$ & $\begin{array}{l}\text { Health, } \\
\text { Workload \& } \\
\text { Attitudes }\end{array}$ & $\begin{array}{l}\text { Productivity \& } \\
\text { Quality }\end{array}$ & $\begin{array}{l}\text { Extensive application of HF } \\
\text { has saved over } \$ 130 \text { in } 17 \\
\text { years } \\
\text { (WIN - WIN) }\end{array}$ \\
\hline
\end{tabular}




\begin{tabular}{|c|c|c|c|c|}
\hline $\begin{array}{l}\text { Reference } \\
\text { - Study } \\
\text { description }\end{array}$ & Journal & $\begin{array}{c}\text { Human } \\
\text { Effect }\end{array}$ & $\begin{array}{l}\text { System } \\
\text { Effect }\end{array}$ & Results \\
\hline $\begin{array}{l}\text { (Hull and Azumi, } \\
\text { 1988) } \\
\text { - Survey of } 2500 \\
\text { employees in } 40 \\
\text { companies }\end{array}$ & $\begin{array}{l}\text { Work and } \\
\text { Occupations }\end{array}$ & Attitudes & $\begin{array}{l}\text { Productivity \& } \\
\text { intangibles }\end{array}$ & $\begin{array}{l}\text { HF and technical factors } \\
\text { account for equal amounts } \\
\text { of productivity gain. Morale } \\
\text { improved. } \\
\text { (WIN - WIN) }\end{array}$ \\
\hline $\begin{array}{l}\text { (Hunter et al., } \\
2004 \text { ) } \\
\text { - Case study of } \\
\text { cell production } \\
\text { implementation }\end{array}$ & $\begin{array}{l}\text { Forest } \\
\text { Products } \\
\text { Journal }\end{array}$ & Workload & $\begin{array}{l}\text { Productivity \& } \\
\text { Quality }\end{array}$ & $\begin{array}{l}\text { HF in cell design improved } \\
\text { productivity and reduced } \\
\text { injury risk. } \\
\text { (WIN - WIN) }\end{array}$ \\
\hline $\begin{array}{l}\text { (Ingelgård and } \\
\text { Norrgren, 2001) } \\
\text { - Survey of 69 } \\
\text { companies } \\
\text { conducting } \\
\text { change } \\
\text { (unspecified) } \\
\text { projects }\end{array}$ & $\begin{array}{l}\text { International } \\
\text { Journal of } \\
\text { Industrial } \\
\text { Ergonomics }\end{array}$ & $\begin{array}{l}\text { Quality of } \\
\text { Working Life }\end{array}$ & Productivity & $\begin{array}{l}\text { HF learning strategy } \\
\text { correlates to quality of } \\
\text { working life and economic } \\
\text { output } \\
\text { (WIN - WIN) }\end{array}$ \\
\hline $\begin{array}{l}\text { (Kazmierczak et } \\
\text { al., 2007) } \\
\text { - Simulation } \\
\text { model examining } \\
\text { both performance } \\
\text { and spinal loads }\end{array}$ & $\begin{array}{l}\text { Human } \\
\text { Factors and } \\
\text { Ergonomics in } \\
\text { Manufacturing }\end{array}$ & Workload & Productivity & $\begin{array}{l}\text { Strategy change increases } \\
\text { throughput - and both } \\
\text { increases and decreases } \\
\text { risks. } \\
\text { (COMPLEX) }\end{array}$ \\
\hline $\begin{array}{l}\text { (Lahiri et al., } \\
2005 \text { ) } \\
\text { - Cost models of } \\
\text { ergonomic } \\
\text { interventions }\end{array}$ & $\begin{array}{l}\text { Journal of } \\
\text { Safety } \\
\text { Research }\end{array}$ & Health & Productivity & $\begin{array}{l}\text { Ergonomic interventions } \\
\text { yield financial benefits from } \\
\text { both HE \& SE } \\
\text { (WIN - WIN) }\end{array}$ \\
\hline $\begin{array}{l}\text { (Lanoie, 1996) } \\
\text { - Case of } \\
\text { 'participatory } \\
\text { ergonomics' in a } \\
\text { warehouse }\end{array}$ & Safety Science & $\begin{array}{l}\text { Health \& } \\
\text { Quality of } \\
\text { Working Life }\end{array}$ & $\begin{array}{l}\text { Productivity \& } \\
\text { Intangibles }\end{array}$ & $\begin{array}{l}\text { HF changes were } \\
\text { profitable, some benefits } \\
\text { difficult to quantify. } \\
\text { (WIN - WIN) }\end{array}$ \\
\hline $\begin{array}{l}\text { (Lee, 2005) } \\
\text { - case study of } \\
\text { low cost } \\
\text { workplace } \\
\text { improvements }\end{array}$ & Ergonomics & $\begin{array}{l}\text { Health, } \\
\text { Workload, } \\
\text { Safety }\end{array}$ & Productivity & $\begin{array}{l}\text { HF in job design reduced } \\
\text { injuries, reduced costs, and } \\
\text { increased productivity 10- } \\
30 \% \\
\text { (WIN - WIN) }\end{array}$ \\
\hline $\begin{array}{l}\text { (Lin et al., 2001) } \\
\text { - Two-line case } \\
\text { study in camera } \\
\text { assembly }\end{array}$ & $\begin{array}{l}\text { Human } \\
\text { Factors and } \\
\text { Ergonomics in } \\
\text { Manufacturing }\end{array}$ & Workload & Quality & $\begin{array}{l}\text { Poor HF and short times } \\
\text { linked to } 50 \% \text { of quality } \\
\text { variance. } \\
\text { (LOSE - LOSE) }\end{array}$ \\
\hline $\begin{array}{l}\text { (Lutz et al., 2000) } \\
\text { - Experimental } \\
\text { evaluation of an } \\
\text { assembly assist } \\
\text { device }\end{array}$ & Ergonomics & Workload & Productivity & $\begin{array}{l}\text { HF device improved } \\
\text { posture but increased task } \\
\text { time by } 13-23 \% \text { without full } \\
\text { training } \\
\text { (WIN - LOSE) }\end{array}$ \\
\hline $\begin{array}{l}\text { (Morag, 2007) } \\
\text { - Case description } \\
\text { of applying HF } \\
\text { programmatically }\end{array}$ & $\begin{array}{l}\text { Applied } \\
\text { Ergonomics }\end{array}$ & $\begin{array}{l}\text { Health, } \\
\text { Workload }\end{array}$ & Productivity & $\begin{array}{l}\text { Applying HF systematically } \\
\text { helps control injuries while } \\
\text { improving performance. } \\
\text { (WIN - WIN) }\end{array}$ \\
\hline
\end{tabular}




\begin{tabular}{|c|c|c|c|c|}
\hline $\begin{array}{l}\text { Reference } \\
\text { - Study } \\
\text { description }\end{array}$ & Journal & $\begin{array}{c}\text { Human } \\
\text { Effect }\end{array}$ & $\begin{array}{l}\text { System } \\
\text { Effect }\end{array}$ & Results \\
\hline $\begin{array}{l}\text { (Moreau, 2003) } \\
\text { - Case overview } \\
\text { of ergonomics } \\
\text { approach at } \\
\text { Peugeot }\end{array}$ & $\begin{array}{l}\text { Applied } \\
\text { Ergonomics }\end{array}$ & $\begin{array}{l}\text { Health \& } \\
\text { Workload }\end{array}$ & Productivity & $\begin{array}{l}\text { Increases in work density } \\
\text { (productivity) increased } \\
\text { MSD symptoms despite } \\
\text { efforts to apply HF. } \\
\text { (LOSE - WIN) }\end{array}$ \\
\hline $\begin{array}{l}\text { (Motamedzade et } \\
\text { al., 2003) } \\
\text { - Case study of } \\
\text { participatory } \\
\text { ergonomics }\end{array}$ & $\begin{array}{l}\text { International } \\
\text { Journal of } \\
\text { Occupational } \\
\text { Safety and } \\
\text { Ergonomics } \\
\end{array}$ & $\begin{array}{l}\text { Health, } \\
\text { Workload, \& } \\
\text { Quality of } \\
\text { Working Life }\end{array}$ & $\begin{array}{l}\text { Productivity \& } \\
\text { Quality }\end{array}$ & $\begin{array}{l}\text { Participatory application of } \\
\text { HF improves efficiency } \\
\text { (WIN - WIN_ }\end{array}$ \\
\hline $\begin{array}{l}\text { (Neumann et al., } \\
\text { 2002) }\end{array}$ & IJPR & Workload & Productivity & $\begin{array}{l}\text { Automation implementation } \\
\text { decreased monotonous } \\
\text { work for some increased it } \\
\text { for others } \\
\text { (COMPLEX) }\end{array}$ \\
\hline $\begin{array}{l}\text { (Neumann et al., } \\
2006) \\
\text { - Case } \\
\text { comparison of two } \\
\text { different } \\
\text { manufacturing } \\
\text { strategies }\end{array}$ & $\begin{array}{l}\text { International } \\
\text { Journal of } \\
\text { Operations } \\
\text { and Production } \\
\text { Management }\end{array}$ & $\begin{array}{l}\text { Health, } \\
\text { Attitudes, } \\
\text { Workload }\end{array}$ & Productivity & $\begin{array}{l}\text { System design choices } \\
\text { have direct and interactive } \\
\text { effects on HF and system } \\
\text { performance } \\
\text { (COMPLEX) }\end{array}$ \\
\hline $\begin{array}{l}\text { (Oxenburgh and } \\
\text { Marlow, 2005) } \\
\text { - Case } \\
\text { demonstration of } \\
\text { the economic } \\
\text { effects of HF bsed } \\
\text { change }\end{array}$ & $\begin{array}{l}\text { Journal of } \\
\text { Safety } \\
\text { Research }\end{array}$ & $\begin{array}{l}\text { Health, } \\
\text { Workload }\end{array}$ & $\begin{array}{l}\text { Productivity \& } \\
\text { Quality }\end{array}$ & $\begin{array}{l}\text { Intervention reduces injury, } \\
\text { and improves quality and } \\
\text { performance } \\
\text { (WIN - WIN) }\end{array}$ \\
\hline $\begin{array}{l}\text { (Parenmark et al., } \\
\text { 1993) } \\
\text { - Case study of } \\
\text { HF redesign }\end{array}$ & $\begin{array}{l}\text { International } \\
\text { Journal of } \\
\text { Industrial } \\
\text { Ergonomics }\end{array}$ & $\begin{array}{l}\text { Health, } \\
\text { Workload }\end{array}$ & $\begin{array}{l}\text { Productivity \& } \\
\text { Quality }\end{array}$ & $\begin{array}{l}\text { HF redesign improved } \\
\text { health, productivity and } \\
\text { performance, reduced } \\
\text { workload and turnover } \\
\text { (WIN - WIN) }\end{array}$ \\
\hline $\begin{array}{l}\text { (Park et al., 2001) } \\
\text { - Survey of tier } 1 \\
\text { suppliers to an } \\
\text { automotive OEM }\end{array}$ & $\begin{array}{l}\text { Journal of } \\
\text { Operations } \\
\text { Management }\end{array}$ & Attitudes, QWL & $\begin{array}{l}\text { Productivity, } \\
\text { Quality \& } \\
\text { Intangibles }\end{array}$ & $\begin{array}{l}\text { High rated suppliers have } \\
\text { better HF that emphasise } \\
\text { employee satisfaction than } \\
\text { do low rated suppliers. } \\
\text { (WIN - WIN) }\end{array}$ \\
\hline $\begin{array}{l}\text { (Rhijn et al., } \\
2005) \\
\text { - Case study of } \\
\text { production system } \\
\text { re-design }\end{array}$ & $\begin{array}{l}\text { International } \\
\text { Journal of } \\
\text { Production } \\
\text { Research }\end{array}$ & Workload & Productivity & $\begin{array}{l}\text { HF in system design } \\
\text { secured } 44 \% \text { improved } \\
\text { productivity without } \\
\text { increased MSD risk. } \\
\text { (NULL - WIN) }\end{array}$ \\
\hline $\begin{array}{l}\text { (Sen and Yeow, } \\
\text { 2003) } \\
\text { - Intervention } \\
\text { case study in } \\
\text { electronics } \\
\text { assembly }\end{array}$ & $\begin{array}{l}\text { Applied } \\
\text { Ergonomics }\end{array}$ & $\begin{array}{l}\text { Attitudes \& } \\
\text { Safety }\end{array}$ & $\begin{array}{l}\text { Quality \& } \\
\text { Productivity }\end{array}$ & $\begin{array}{l}\text { Product redesign improved } \\
\text { both OHS performance and } \\
\text { improved quality related } \\
\text { costs; benift:cost ratio } \\
245.8 x \\
\text { (WIN - WIN) }\end{array}$ \\
\hline $\begin{array}{l}\text { (Shikdar and } \\
\text { Sawaqed, 2003) } \\
\text { - Survey of } 50 \\
\text { production } \\
\text { managers }\end{array}$ & $\begin{array}{l}\text { Computers in } \\
\text { Industrial } \\
\text { Engineering }\end{array}$ & $\begin{array}{l}\text { Health, } \\
\text { Attitudes, } \\
\text { Workload \& } \\
\text { Safety }\end{array}$ & Productivity & $\begin{array}{l}\text { HF problems in OS } \\
\text { correlated to poor } \\
\text { performance and } \\
\text { absenteeism. } \\
\text { (LOSE - LOSE) }\end{array}$ \\
\hline
\end{tabular}




\begin{tabular}{|c|c|c|c|c|}
\hline $\begin{array}{l}\text { Reference } \\
\text { - Study } \\
\text { description }\end{array}$ & Journal & $\begin{array}{c}\text { Human } \\
\text { Effect }\end{array}$ & $\begin{array}{c}\text { System } \\
\text { Effect }\end{array}$ & Results \\
\hline $\begin{array}{l}\text { (Shikdar and Das, } \\
\text { 2003) } \\
\text { - Experiment of } \\
\text { different } \\
\text { production } \\
\text { standard setting } \\
\text { and feedback } \\
\text { approaches }\end{array}$ & Ergonomics & Attitudes & Productivity & $\begin{array}{l}\text { Participation and feedback } \\
\text { in production standard } \\
\text { setting improves attitudes } \\
\text { and performance. } \\
\text { (WIN - WIN) }\end{array}$ \\
\hline $\begin{array}{l}\text { (Smith, 1999) } \\
\text { - Descriptions of } \\
\text { case description } \\
\text { illustrated with } \\
\text { examples }\end{array}$ & \begin{tabular}{|l|} 
International \\
Journal of \\
Occupational \\
Safety and \\
Ergonomics
\end{tabular} & Safety & $\begin{array}{l}\text { Productivity \& } \\
\text { Quality }\end{array}$ & $\begin{array}{l}\text { Including HF in system } \\
\text { design improves safety, } \\
\text { performance and quality } \\
\text { (WIN - WIN) }\end{array}$ \\
\hline $\begin{array}{l}\text { (Sundin et al., } \\
2004) \\
\text { - Case study of } \\
\text { participatory } \\
\text { ergonomics in } \\
\text { product design }\end{array}$ & $\begin{array}{l}\text { International } \\
\text { Journal of } \\
\text { Industrial } \\
\text { Ergonomics }\end{array}$ & Workload & Productivity & $\begin{array}{l}\text { Design for Manufacture } \\
\text { improves efficiency and HF } \\
\text { in assembly } \\
\text { (WIN - WIN) }\end{array}$ \\
\hline $\begin{array}{l}\text { (Tjosvold, 1998) } \\
\text { - Interviews of } 60 \\
\text { employees in } 1 \\
\text { company }\end{array}$ & $\begin{array}{l}\text { Human } \\
\text { Relations }\end{array}$ & Attitudes & $\begin{array}{l}\text { Productivity \& } \\
\text { Intangibles }\end{array}$ & $\begin{array}{l}\text { Use of cooperative goals } \\
\text { resulted in improved } \\
\text { communication, } \\
\text { performance, and } \\
\text { employee commitment. } \\
\text { (WIN - WIN) }\end{array}$ \\
\hline $\begin{array}{l}\text { (Udo and } \\
\text { Ebiefung, 1999) } \\
\text { - Survey of } 92 \\
\text { companies on } \\
\text { their advanced } \\
\text { manufacturing } \\
\text { implementation }\end{array}$ & $\begin{array}{l}\text { Computers in } \\
\text { Industrial } \\
\text { Engineering }\end{array}$ & Attitudes & Implementation & $\begin{array}{l}\text { Implementation of } \\
\text { advanced manufacturing } \\
\text { systems improves with } \\
\text { application of HF principles } \\
\text { (WIN - WIN) }\end{array}$ \\
\hline $\begin{array}{l}(\mathrm{Vi}, 2006) \\
\text { - Case study of } \\
\text { automation }\end{array}$ & Ergonomics & Workload & Productivity & $\begin{array}{l}\text { Automation can reduce } \\
\text { back injury risk and } \\
\text { increase productivity } \\
\text { (WIN - WIN) }\end{array}$ \\
\hline $\begin{array}{l}\text { (Victor et al., } \\
\text { 2000) } \\
\text { - Survey with } 213 \\
\text { employees in } 10 \\
\text { plants from } 1 \\
\text { company }\end{array}$ & $\begin{array}{l}\text { Organisational } \\
\text { Science }\end{array}$ & Attitudes & $\begin{array}{l}\text { Implementation } \\
\text { \& Intangibles }\end{array}$ & $\begin{array}{l}\text { Effective employee } \\
\text { switching strategy } \\
\text { associated with better TQM } \\
\text { functioning, with less } \\
\text { stress and greater job } \\
\text { satisfaction } \\
\text { (WIN - WIN) }\end{array}$ \\
\hline $\begin{array}{l}\text { (Yeow and Sen, } \\
\text { 2004) } \\
\text { - Case Study of } \\
\text { workstation re- } \\
\text { design }\end{array}$ & $\begin{array}{l}\text { International } \\
\text { Journal of } \\
\text { Occupational } \\
\text { Safety and } \\
\text { Ergonomics }\end{array}$ & Health & $\begin{array}{l}\text { Productivity \& } \\
\text { Quality }\end{array}$ & $\begin{array}{l}\text { Applying HF in re-design } \\
\text { improves quality and } \\
\text { efficiency } \\
\text { (WIN -WIN) }\end{array}$ \\
\hline $\begin{array}{l}\text { (Yeow and Sen, } \\
2003) \\
\text { - Case study of } \\
\text { workstation } \\
\text { redesign }\end{array}$ & $\begin{array}{l}\text { International } \\
\text { Journal of } \\
\text { Industrial } \\
\text { Ergonomics }\end{array}$ & $\begin{array}{l}\text { Workload, } \\
\text { Safety }\end{array}$ & $\begin{array}{l}\text { Productivity \& } \\
\text { Quality }\end{array}$ & $\begin{array}{l}\text { Applying HF in re-design } \\
\text { improves quality and } \\
\text { efficiency } \\
\text { (WIN - WIN) }\end{array}$ \\
\hline
\end{tabular}




\begin{tabular}{|c|c|c|c|c|}
\hline $\begin{array}{c}\text { Reference } \\
\text { - Study } \\
\text { description }\end{array}$ & Journal & $\begin{array}{l}\text { Human } \\
\text { Effect }\end{array}$ & $\begin{array}{l}\text { System } \\
\text { Effect }\end{array}$ & Results \\
\hline $\begin{array}{l}\text { (Yeow and Sen, } \\
2006) \\
\text { - Case study of } \\
\text { workstation } \\
\text { redesign }\end{array}$ & $\begin{array}{l}\text { International } \\
\text { Journal of } \\
\text { Industrial } \\
\text { Ergonomics }\end{array}$ & $\begin{array}{l}\text { Workload, } \\
\text { Attitudes }\end{array}$ & $\begin{array}{l}\text { Productivity \& } \\
\text { Quality }\end{array}$ & $\begin{array}{l}\text { Applying HF in re-design } \\
\text { improves quality and } \\
\text { efficiency } \\
\text { (WIN - WIN) }\end{array}$ \\
\hline
\end{tabular}

